UNITED STATES DEPARTMENT OF THE INTERIOR

GEOLOGICAL SURVEY

\title{
Geochemical assessment of mineral resources in the \\ Park Range Survey Area (NV 040-154), \\ in south-central Mevada
}

By

Robert E. Tucker, Christopher Goodhue, and Gordon W. Day

Open-File Report

$84-102$

This report is preliminary and has not been reviewed for conformity with U.S. Geological Survey editorial standards. Any use of trade names is for descriptive purposes only and does not imply endorsement by the U.S. Geological Survey. 


\section{Table of Contents}

Page

Abstract................................................ 1

Introduction. ............................................. 1

Sample collection, and analytical techniques ..................... 3

Discussion and interpretation of results....................... 6

Geology .............................................. 6

Energy and Mineral Resources.................................. 7

Land Classification for G-E-M Resources Potential................. 7

A. Locatable Resources.................................... 9

Metallic Minerals.................................. 9

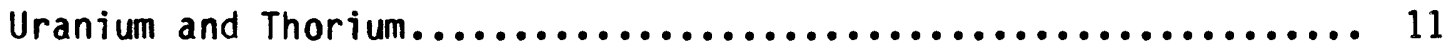

Nonmetallic Minerals................................ 13

B. Leasable Resources.................................. 13

$0 i 1$ and Gas Resources.............................. 13

Geothermal Resources.............................. 16

Sodium and Potassium Resources......................... 16

C. Saleable Resources.................................. 16

Recommendations for additional work.......................... 18

References Cited........................................ 18

\section{List of Figures}

Figure 1.--Index map of the Park Range Resource Survey Area,

south-Central Nevada................................. 2

Figure 2.--Sampling sites within the Park Range Resource Survey

Area, south-central Nevada.............................. 4

Figure 3.--Land classification for metallic mineral occurrences in the Park Range Resource Survey Area, south-central Nevada........ 10 
Figure 4.--Land classification for uranium mineral occurrences in the Park Range Resource Survey Area, south-central Nevada.... 12

Figure 5.--Land classification for nonmetallic mineral occurrences in the Park Range Resource Survey Area, south-central Nevada.... 14

Figure 6.--Land classification for oil and gas leasable resources in the Park Range Resource Survey Area, south-central Nevada.... 15

Figure 7.--Land classification for geothermal leasable resources in the Park Range Resource Survey Area, south-central Nevada.... 17

\section{List of Tables}

Table 1.--Bureau of Land Management Classification scheme and level of confidence scheme................................

\section{Appendix}

Appendix 1.--Data summary for the minus-80-mesh fraction of the stream-sediment samples in the Park Range Resource Survey Area, south-central Nevada.....................

Appendix 2.--Data summary for the panned-concentrate fraction of the stream-sediment samples in the Park Range Resource Survey Area, south-central Nevada. 


\section{Abstract}

A stream sediment geochemical survey of the Park Range Resource Survey Area (NV 040-154) was conducted as part of the Bureau of Land Management Phase II mineral resource evaluation. During the summer of 1983, stream-sediment samples were collected from 53 first-order drainage basins within the resource area. The geochemical evaluation utilized the minus-80-mesh fraction of the stream-sediment samples and the nonmagnetic fraction of panned concentrate from stream-sediment samples. The lack of geochemically anomalous elemental concentrations from either sample media indicates the survey area has a low potential for metallic mineral resources. The Antelope/Park Range G-E-M Resources Area Technical Report, which is a literature review of the area, also indicated the Park Range Resource Survey Area has low mineral resource potential.

\section{Introduction}

The Park Range Resource Survey Area is located in south-central Nevada approximately 45 miles northwest from the village of Warm Springs (figure 1). The area is located in the Basin and Range physiographic province and contains 47,268 acres. The predominant rock type is the Tertiary Windous Butte Formation, comprising a sequence of ash-flow tuffs of quartz latite to rhyolite composition. Scattered occurrences of older dacitic to andesitic composition lavas also occur within the survey area. In the northwestern portion of the survey area, Ordovician, Devonian, and Pennsylvanian sedimentary rocks are exposed (anonymous, 1983). 


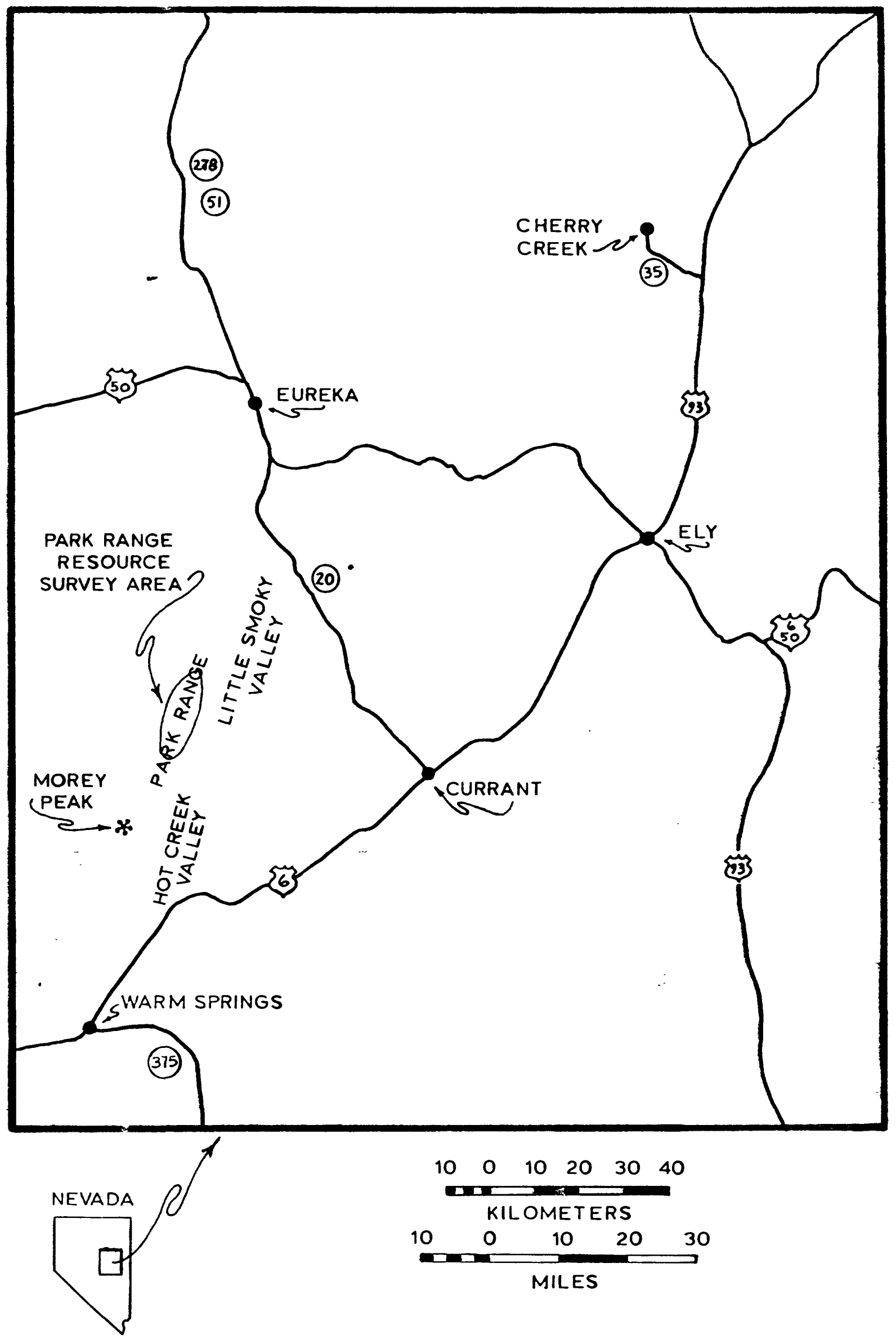

Figure 1.---Index map of the Park Range Resource Survey Area, south-central Nevada. 


\section{Sample Collection and Analytical Techniques}

Minus-80-mesh stream-sediment and panned-concentrates from streamsediment samples were collected during the summer of 1983. A composite stream-sediment sample was collected at each site. The sample consisted of sediments collected from not less than five points along approximately 100 feet of the stream channel (figure 2). Approximately 10-15 pounds of minus-2-mm sediment was collected in a large gold pan and hand mixed. About 0.5 pounds of the mixed sediment was placed in a Kraft paper bag and later sieved to minus-80-mesh. The minus-80-mesh fraction of the stream-sediment sample was oven dried at $90^{\circ} \mathrm{C}$.

The second sample consisted of the remainder of the mixed sediment which was placed in a cotton sack. This sample was later panned to remove the bulk of the common rock-forming minerals such as feldspar, quartz, and calcite. The concentrate was dried and sieved to minus-35-mesh and was then placed in bromoform (specific gravity $=2.86$ ) to remove the remaining feldspar, quartz, calcite, and other rock-forming minerals which are lighter than bromoform. The resultant heavy-mineral separates which are heavier than bromoform may contain minerals, such as magnetite, ilmenite, sphene, barite, biotite, hornblende, sulfides, and certain oxides. The magnetite and ilmenite were removed from the heavy-mineral separates using an electromagnet that was placed horizontally, with mylar over the poles. The electromagnet was set at 0.4 amperes. The concentrate was placed on a mylar covered tray which was moved slowly to a distance approximately 4-6 inches below the poles, which attracted the magnetite to the magnet. The magnetite was removed from the poles. The electromagnet was then set at 1.8 amperes. The tray was brought in contact with the magnet and moved slowly across the opening between the poles. This procedure removes the minerals that are magnetic at a 0.6 ampere 


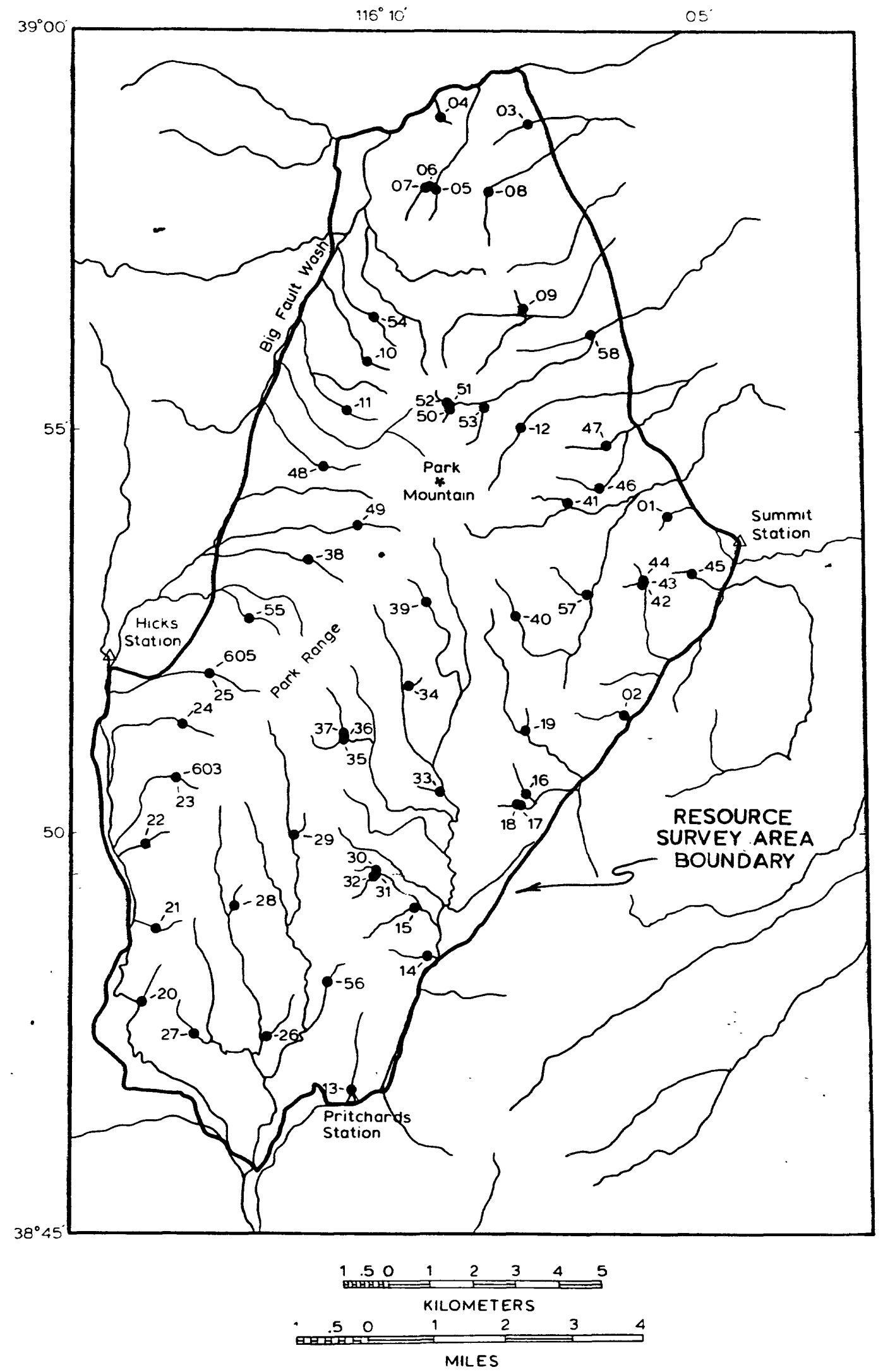

Figure 2.--Sampling sites within the Park Range Resource Survey Area, south-central Nevada. 
setting when a Frantz Isodynamic Separator is used as discussed in Flinter (1959), Hess (1956), and Nickel $(1968,1969)$, with $15^{\circ}$ forward slope and $10^{\circ}$ side slope. The mineral grains left on the tray were nonmagnetic at a 0.6 amperage. The magnetic splits of the panned concentrates may contain minerals such as biotite, sphene, pyroxene, hornblende, and garnet. The nonmagnetic splits may contain minerals such as topaz, sphene, rutile, hematite, sulfides, some sulfates, carbonates, and oxides. The nonmagnetic fraction of the panned concentrate was split using a micro splitter and a representative sample was pulverized in an agate crucible.

All samples were randomized and then analyzed by a six-step D.C.-arc semiquantitative emission spectrographic method for 31 elements (Grimes and Marranzino, 1968). All of the analytical values are reported as six steps per order of magnitude $(1,1.5,2,3,5,7$, or multiples of 10). These values approximate the geometric midpoints of successive concentration ranges (Grimes and Marranzino, 1968). The spectrographic method utilizes a series of elemental standards against which the elemental concentrations in the samples are compared. If a sample contains elemental concentrations above the highest standard used in the six-step D.C.-arc spectrographic method, the elemental concentration is given a "G" code. If a sample contains elemental concentrations below the lowest standard used in the six-step D.C.-arc spectrographic method, two code designations can be assigned for the concentration; if the sample concentration is slightly below the lowest standard, the elemental concentration is given an "L" code; if the sample concentrations is not detected, the elemental concentration is given an " $N$ " code. The six-step D.C.-arc emission spectrographic method provides reproducibility within one reporting unit of the reported value approximately 88 percent of the time and within two reporting units of the reported value approximately 96 percent of the time (Motooka and Grimes, 1976). 
When analyzing the nonmagnetic fraction of the panned concentrate samples, a modification of the spectrographic method was necessary to eliminate spectral interferences produced by matrix effects characteristic of this sample type. The effect of this modification was a loss of sensitivity resulting in an increase of all lower limits of determination by two reporting units. The analytical results for the minus-80-mesh stream sediments and the nonmagnetic fraction of the panned concentrates are given in Appendix 1 and 2.

\section{Discussion and interpretation of results}

The analytical data were visually examined for above background elemental concentrations that might be related to mineralization. No anomalous metal concentrations unrelated to lithology can be identified within the minus-80-mesh fraction of the stream-sediment samples or the nonmagnetic fraction of the panned concentrate. The analytical results suggest that the resource survey area has a low potential for containing potential mineral deposits.

\section{Geology}

The Park Range WSA is located within the Basin and Range province in northern Nye County, Nevada. The Park Range is a northeast trending fault block that dips slightly to the southeast. Outcrops in the area are predominantly Tertiary volcanic rocks that range in composition from andesites to rhyolites. Small amounts of Paleozoic sedimentary rocks are present in the northwestern portion of the WSA. Detailed descriptions of the physiography, rock units, structural geology and tectonics, paleontology, and historical geology are found in the G-E-M report on the Antelope/Park Range Resources Area (anonymous, 1983). 


\section{Energy and Mineral Resources}

Mines in the Morey district, located approximately 10 miles south of the Park Range Resource Area produced mostly silver during the last half of the 1800 's. Several prospects lie to the north of the Morey district within the southern Antelope Range, but no prospects were observed within the survey area. A detailed description of mining claims and deposit types, for both metallic and nonmetallic mineral resources, is included in the G-E-M report for this area (anonymous, 1983).

\section{Land Classification For G-E-M Resources Potential}

Land classification areas are numbered starting with the number 1 in each category of resources. Metallic mineral land classification areas have the prefix M, e.g., M1-4D. Uranium and thorium areas have the prefix U. Nonmetallic mineral areas have the prefix $N, 0 i l$ and gas areas have the prefix 0G. Geothermal areas have the prefix G. Sodium and potassium areas have the prefix $S$. The saleable resources are classified under the nonmetallic mineral resource section. Both the Classification Scheme, numbers 1 through 4, and the Level of Confidence Scheme, letters A, B, C, and D, as supplied by the BLM are included in this report (Table 1 ).

Land classifications have been given to the resource survey area. Where data outside the resource survey area have been used in establishing a classification within a survey area, then at least a part of the surrounding area may also be included for clarification. The land classification maps in this report are at a $1: 250,000$ scale. 
Table 1.--Bureau of Land Management classification scheme and level of confidence scheme.

\section{Classification Scheme}

1. The geologic environment and the inferred geologic processes do not indicate favorability for accumulation of mineral resources.

2. The geologic environment and the inferred geologic processes indicate low favorability for accumulation of mineral resources.

3. The geologic environment, the inferred geologic processes, and the reported mineral occurrences indicate moderate favorability for accumulation of mineral resources.

4. The geologic environment, the inferred geologic processes, the reported mineral occurrences, and the known mines or deposits indicate high favorability for accumulation of mineral resources.

\section{Level of Confidence Scheme}

A. The available data are either insufficient and/or cannot be considered as direct evidence to support or refute the possible existence of mineral resources within the respective area.

B. The available data provide indirect evidence to support or refute the possible existence of mineral resources.

C. The available data provide direct evidence, but are quantitatively minimal to support or refute the possible existence of mineral resources.

D. The available data provide abundant direct and indirect evidence to support or refute the possible existence of mineral resources. 
In connection with nonmetallic mineral classification, it should be noted that in all instances areas mapped as alluvium are classified as having moderate favorability for sand and gravel, with moderate confidence, because alluvium is by definition sand and gravel. All areas mapped as "other rock," if they do not have specific reason for a different classification, are classified as having low favorability, with low confidence, for nonmetallic mineral potential.

A. Locatable Resources

Metallic Minerals

M1-2B. This classification covers the entire resource survey area (figure 3 ). Almost the entire survey area is covered with Tertiary rocks related to the Williams Ridge caldera complex, but small areas of Paleozoic sedimentary rocks are exposed. Most of the sedimentary rocks are limestones or dolomites which are favorable for the accumulation of base metal sulfide mineral deposits. Numerous faults occur in these rocks, including thrust faults, that can provide suitable structural environments for mineral deposits. The nearby Williams Ridge caldron suggests a large magma body may underlie the area and may have been the source of mineralizing solutions that migrated into the surrounding rocks. The rocks have a high favorability for containing base metal sulfide mineral deposits but no mining or prospects occur in the area. The low level of confidence in this classification stems from the fact that no direct geochemical evidence of mineralization exists within the survey area. 


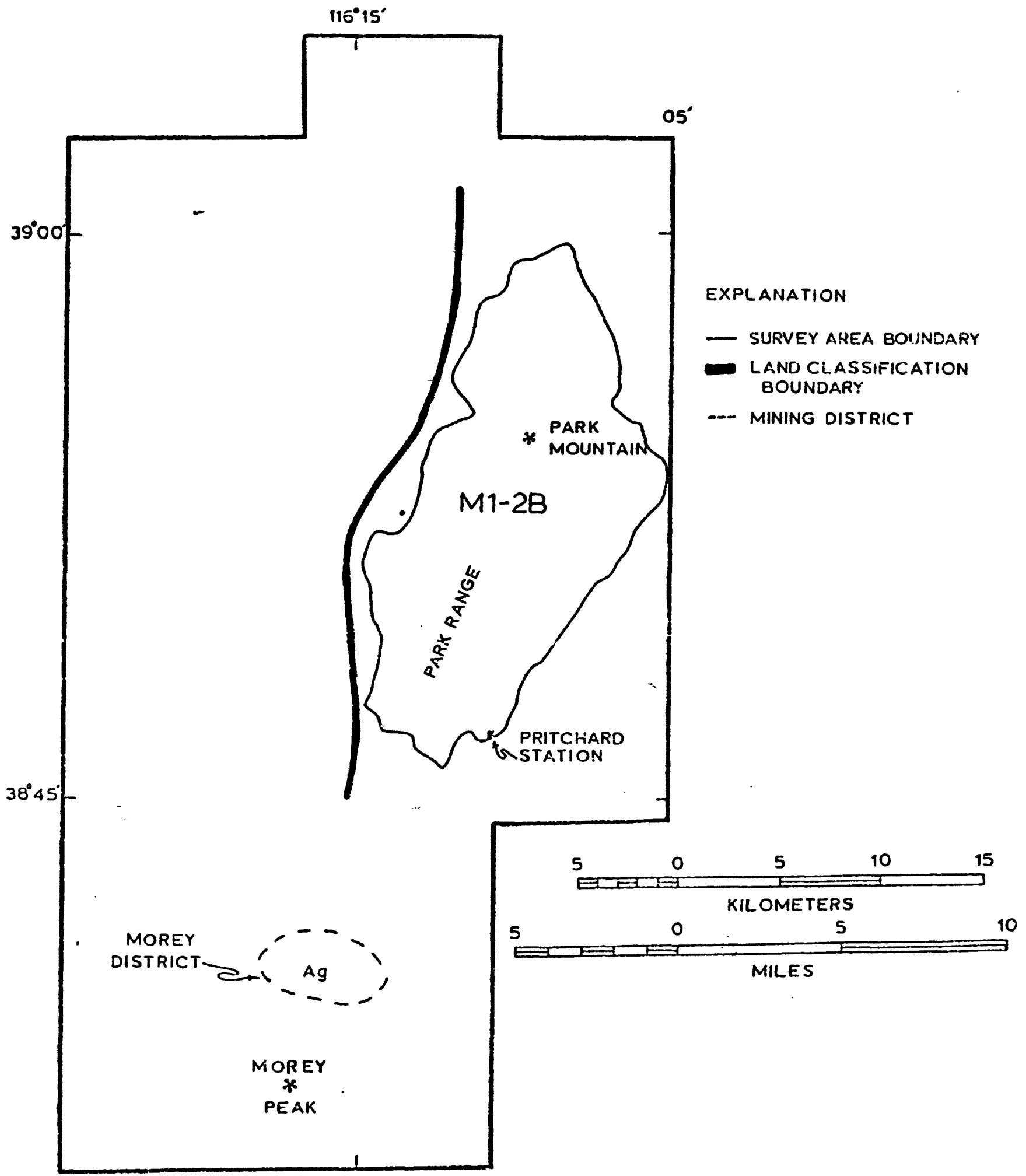

Figure 3.--Land classification for metallic mineral occurrences in the Park Range Resource Survey Area, south-central Nevada. 
Uranium and Thorium

U1-2B. This land classification covers most of the resource survey (figure 4 ). These areas mostly consist of Tertiary welded ash-flow tuffs, with relatively minor amounts of Paleozoic sedimentary rocks exposed in the northern tip of the survey area. The areas have low favorability at a low confidence level for fracture filled uranium deposits in the tuffs and sedimentary rocks. The development of the Hot Creek Valley caldera complex may have produced structural conditions favorable for uranium deposition in fractured tuffs and adjacent Paleozoic sedimentary rocks. One uranium occurrence (Lime Ridge group) has been noted in the ash flow tuffs, indicating that the tuffs may be source rocks for such deposits.

The area has very low favorability for thorium at a very low confidence level due to the lack of known granitic or pegmatitic source rocks.

U2-2B. This land classification covers small areas on the margins of the resource survey area (figure 4). These areas are covered by Quaternary alluvium, and they have low favorability at a low confidence level for epigenetic sandstone-type uranium deposits. Ash-flow tuffs in the mountain ranges are possible sources of uranium, which can be leached by ground water and deposited in chemically reduced areas in the alluvium adjacent to the mountains.

The areas appear to have very low favorability at a very low confidence level for thorium deposits due to the lack of suitable source rocks. 


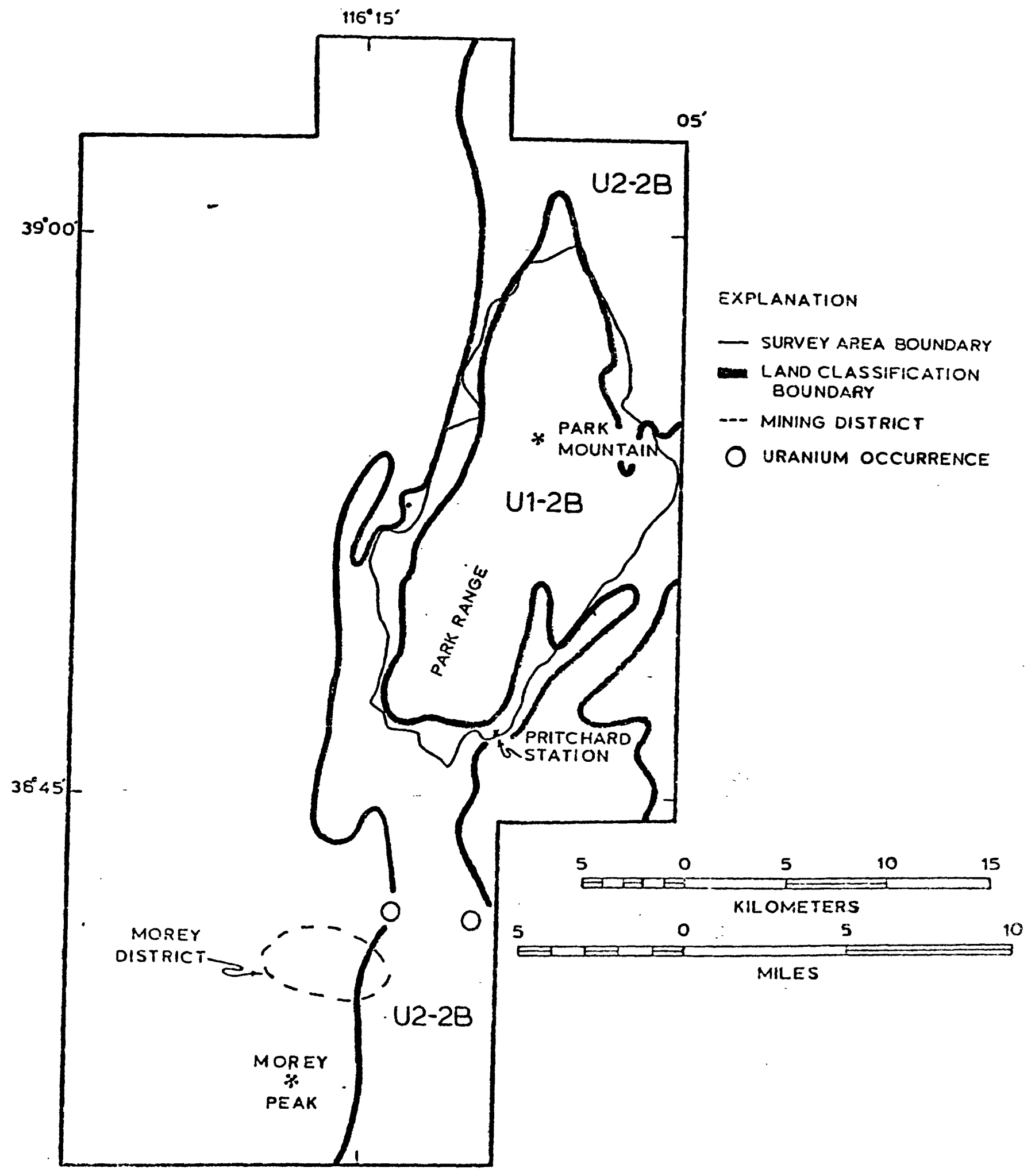

Figure 4.--Land classification for uranium mineral occurrences in the Park Range Resource Area, south-central Nevada. 


\section{Nonméallic Minerals}

$\mathrm{N1-2B}$. This classification covers most of the resource survey area (figure 5). Except for a small area of Paleozoic sedimentary rocks the entire survey area is underlain by Tertiary volcanic rocks. No occurrences of exploitable nonmetallic minerals are known, therefore this area has a low favorability and the low level of confidence in the classification.

N2-3C. This classification covers parts of all the edges of the resource survey area (figure 5), where Quaternary alluvium is mapped because alluvium by definition contains sand and gravel. No sand and gravel is known to have been mined here, which is the reason for the only moderately favorable classification. The quality of the sand and gravel at any point is not known, which is the reason for the moderate level of confidence.

\section{B. Leasable Resources}

\section{$0 i 1$ and Gas}

0G1-2A. This classification covers the entire resource survey area (figure 6). The survey area is underlain by broad, probably fairly thick, sections of Tertiary volcanic rocks and alluvium, which overlies the volcanic rocks. Extensive faulting is present, especially along the range front areas. Erosion at some of these fault dislocations reveals Mississippian, Pennsylvanian, and Permian strata of the Paleozoic age miogeosyncline, the focal point of the petroliferous province of eastern Nevada. These rocks include oil and gas source and reservoir horizons which are present below the volcanic and alluvium exposures. 


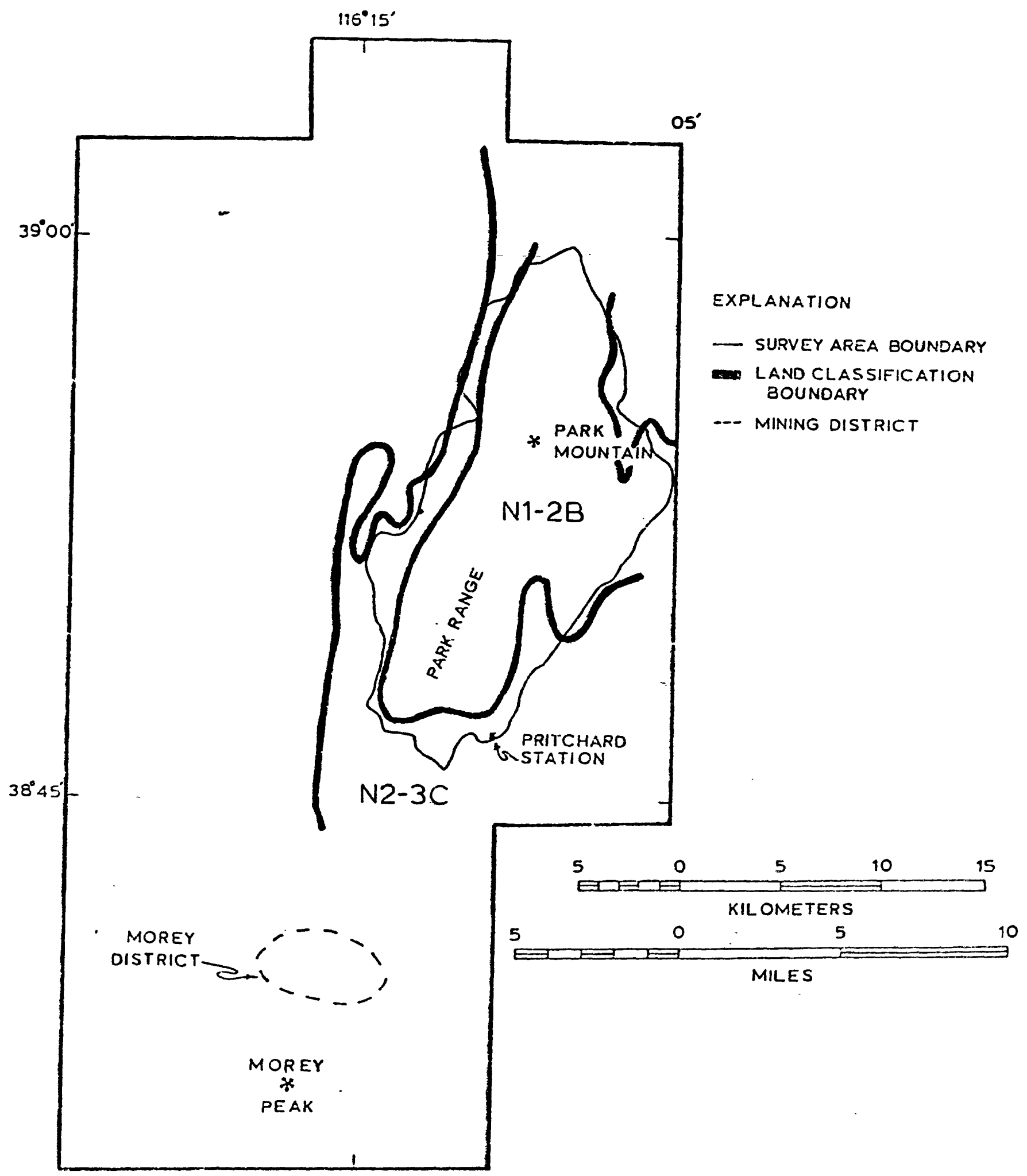

Figure 5.--Land classification for nonmetallic mineral occurrences in the Park Range Resource Survey Area, south-central Nevada. 


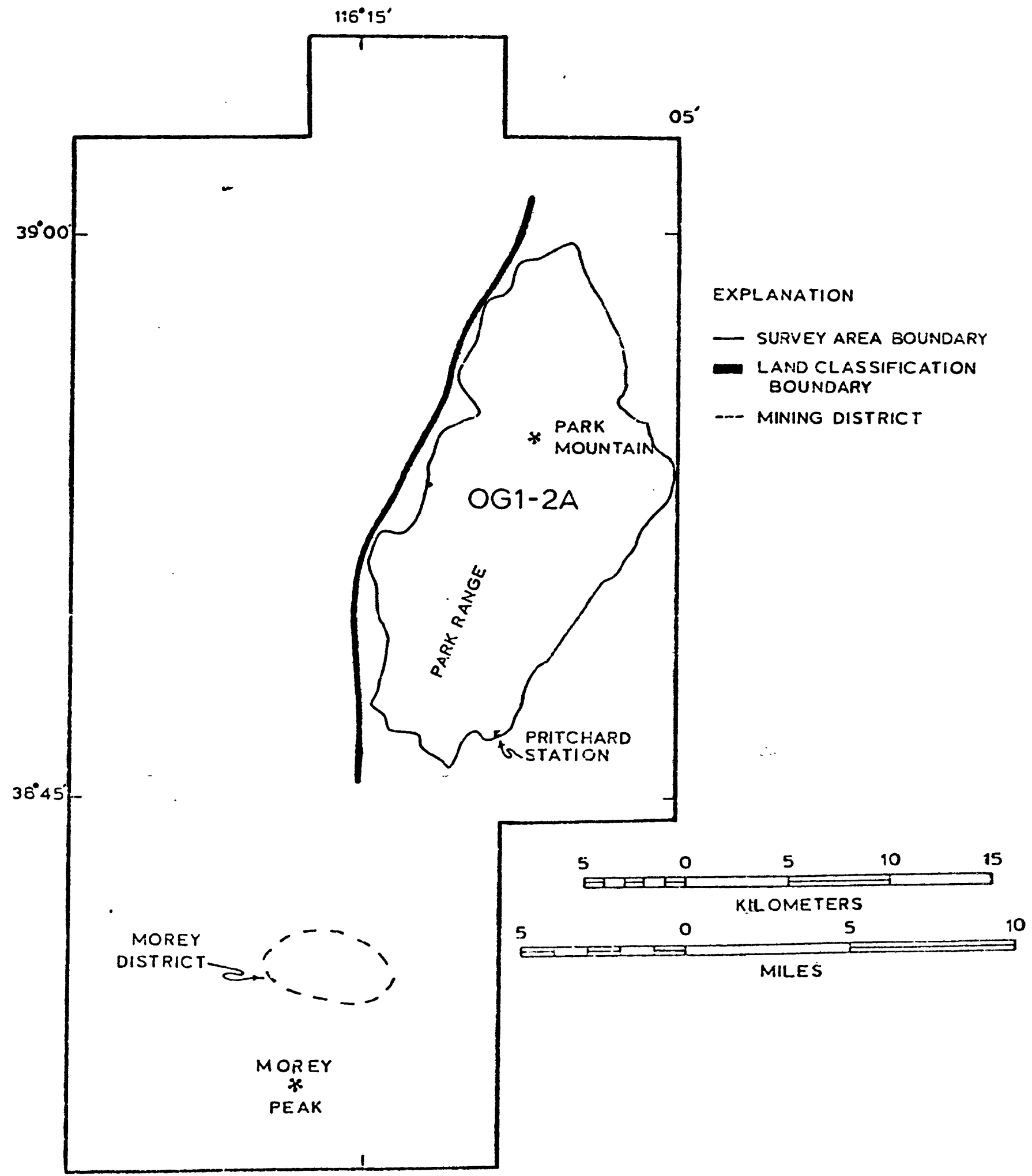

Figure 6.--Land classification for oil and gas leasable resources in the Park Range Resource Survey Area, south-central Nevada. 


\section{Geothermal Resources}

G1-3A. This classification incorporates those portions of the resource survey area that are known to have regional, deep-seated faulting (figure 7). Thermal occurrences are known to exist in wells and springs outside the survey area on structural strike that would project into the survey area. These structural environments are host to literally hundreds of thermal sites in the Nevada portion of the Basin and Range province.

G2-2A. This classification includes the central portion of the resource survey area. This section of the area has low favorability due to the extensive volcanic rock cover and distance from more favorable fault controlled conduits.

\section{Sodium and Potassium}

S1-10. No known potential exists for sodium and potassium resources, and the survey area has very low favorability with high confidence for sodium and potassium. No map is presented for sodium and potassium classification areas.

\section{Saleable Resources}

Saleable resources have been considered in connection with nonmetallic mineral resources. 


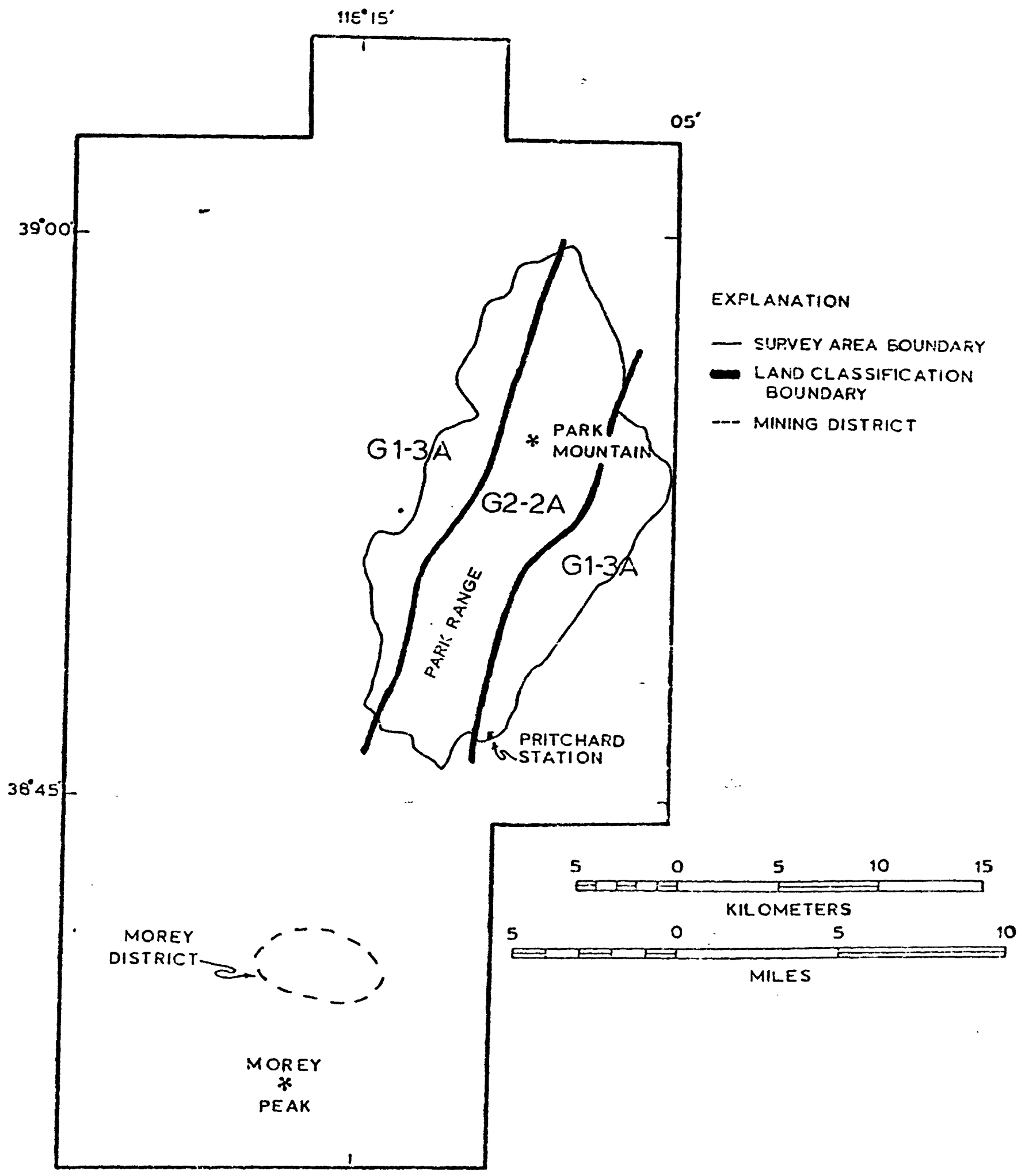

Figure 7.--Land classification for geothermal leasable resources in the Park Range Resource Survey Area, South-central Nevada. 


\section{Recommendations for additional work}

Within the survey area no geochemical anomalies have been recognized that could be related to metallic resources, and additional stream-sediment sampling would not seem warranted.

Further studies using outcrop samples might include petrographic analysis, trace-element geochemistry, and dating. A comparative mineralogy of the soils and sediments and how they relate to the rocks could be undertaken. These pursuits would be of a purely scientific nature, and would not be expected to raise the level of favorability for resource occurrences.

\section{References cited}

(anonymous), 1983, Antelope/Park Range G-E-M Resources Area (GRA No. NV-12)

Technical Report (WSAs NV 040-154 and 060-23/241), Contract

YA-553-RFP2-1054, Prepared by Great Basin GEM Joint Venture, 251 Ralson

Street, Reno, Nevada 89503, April 29, 1983, 33 pp.

Flinter, B. H., 1959, The magnetic separation of some alluvial minerals in

Malaya: American Mineralogist, v. 44, no. 7-8, p. 739-751.

Grimes, D. J., and Marranzino, A. P., 1968, Direct-current arc and

alternating-current spark emission spectrographic field methods for

semiquantitative analysis of geologic materials: U.S. Geological Survey

Circular 591, 6 p.

Hess, H. H., 1956, Notes on operation of Frantz Isodynamic Magnetic Separator: pamphlet published by S. G. Frantz Company, Inc., 8 p. Hurlbut, Cornelius, 1971, Dana's Manual of Mineralogy, John Wiley and Sons, Inc., 579 p.

McAndrew, John, 1957, Calibration of a Frantz Isodynamic Separator and its application to mineral separation: Australasian Institute of Mining and Metallurgy Proceedings No. 181, p. 59-73. 
Motooka, J.M., and Grimes, D. J., 1976, Analytical precision of one-sixth order semiquantitative spectrographic analysis: U.S. Geological Survey Circular 738, 25 p.

Nickel, E. H., 1968, Structural stability of minerals with the pyrite, marcasite, arsenopyrite, and lollingite structures: Canadian Mineralogist, v. 9, pt. 3, p. 311-321. - 1969, The application of ligand-field concepts to an understanding of the structural stabilities and solid solution limits of sulphides and related minerals: Chemical Geology, v. 5, no. 4, p. 233-241. Rosenblum, Samuel, 1958, Magnetic susceptibilities of minerals in the Frantz Isodynamic Magnetic Separator: American Mineralogist, v. 43, no. 1-2, p. $170-173$. 
$0=00$

$\because 0 \geq 00$

00000

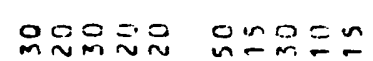

유유은

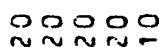

$m=0=m$

$z B \equiv \equiv \approx$

noono unnog onnum nuogo onono - -

$2 \geq 02$

$2 \geq 2 \frac{0}{v}$

$z \geq 2 \frac{0}{v} \quad \frac{0}{v} z 0 z$

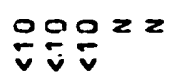

$\frac{0}{v} z 2=$

$\frac{0}{2} \frac{0}{2}=$

क

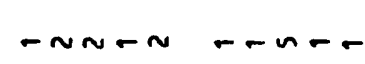

$m+n$

$n-n$

rnor

- n - -

$m-n$

\section{옹ㅇㅇㅇㅇㅇ \\ 공ㅇㅁㅇㅇㅁㅇㅛ \\ 옹용요 \\ 은은 \\ 푸}

옹웅음음

웃오윰

영웅음웅웃

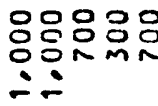

옹응영

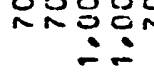

옹응응으

:

E

$\infty$

\section{옹ㅇㅇㅇㅇㅇ \\ 옹요}

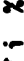

00000

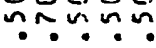

웅오옹응

옷음윰웃

옷욤윰음

政

$0000=$

inimi

00000

minini

00000

주ㄴㅡㅗㄴ은

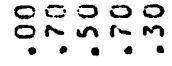

은응ํำ

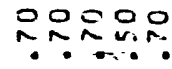

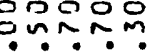

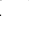

00000

- iñ

우웅

00000

n-n

웅ㅇㅇำ

$\because \because \because \because$

ini:

ำกำ

กำ?

ดะทกา

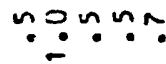

00000

00000

iminis

nivinim

00000

iñmin

iminim

00000

ningin

00000

is

2

은

$\therefore 0 \div m \backsim$

오ํํำ

ogs soo

$\lim _{0} \approx a$

nona a

a. a 00

n?

ara a a

mmmm

00000

00000

-0000

00000

0000

Eะ5

ニニニニニ

๖ேニニニ

モニニニ゙

$\check{E ニ \Xi}$

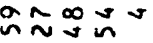

no 0 m

nnmm

"meñ

스는든

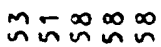

๙

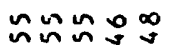

근은용

$\infty_{m \infty m m}^{\infty} \infty$

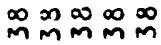

$\infty \infty \infty \infty$

$\infty \infty \infty \infty$

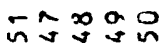

$\infty \infty \infty m \infty$
$m m m m$

no. wos

$m \sim=m \sim$

누을

-0으응

00000

$\div \div \div=$

잉ㅇㅇ

둔든

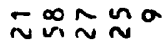

ㄸำ

m $m$ m m m
冓요요

a g o g g

$\infty m \infty \infty \infty$
22

$\frac{0}{v}=$

$x \frac{x^{2}}{2}=\frac{2}{2}$

웅용용

애음요

$\therefore:$

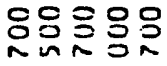

은 은은

$\therefore$

은은유 은은군유

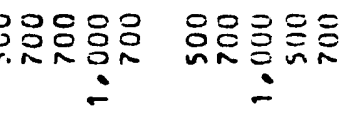

0000

ㄷ․ㄹ.

은을

00000 o:? = vinin $\dot{i n i m i n}$

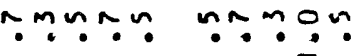

00000 inini

00000 ํ்பำ

nimoo

on $n \infty \infty$

a 0000

$0=a \sim n$

00000

ㄷำ

00000

$\because \div \div \div \div$

을

只药药的

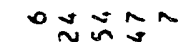

$\infty \infty \infty \infty \infty$

$-m \tilde{\sim} \sim \tilde{n}$

$\infty \underset{m m \infty}{\infty} \infty \begin{gathered}\infty \\ m m\end{gathered}$
กิㅇํㅇ

nก⿻上丨 nunun

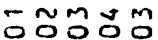

o.0. nn 的的里 융ㅇㅇㅇ nvinun

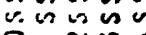
DNㅜㄴ $\therefore \approx$ जn น $\sim 20$. ns $n$ in $n$ is on को - an $\sin$ on in $n$ in $\sim \sim \sim \sim ⿻ \infty$
응 แ n แลำ $\sim \sim \sim \tilde{m})$

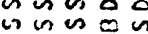
miñ $\therefore$

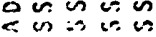
ल心 
⿷

a

E

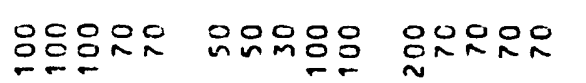

E

: is

ह

$\frac{5}{2}$

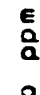

$\stackrel{\circ}{a}$

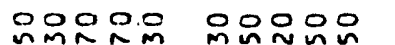

우ㄹㅡㅠ뭇요

움ํㅜ윰요

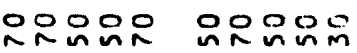

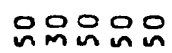

onmno ornun unninn

$\sin \sin$

กn ヘ

nnoㅇㅇㅇ

咅 z

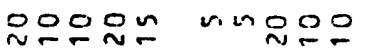

nnungo

은nn

ngngon

우으묘

onong

onnmn

no요

à

opogo

\section{co000}

\section{옴ํำ}

응요욤

우윰

우윰유

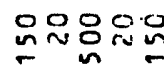

쿡모윰유

문요욤

E⿱ 3

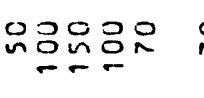

우숭ㅇㅇㅇ

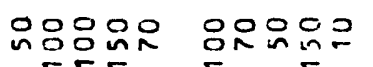

은으뭉용

은응ㅇㅁㅇㅇㅇ

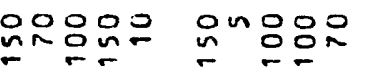

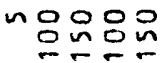

$\stackrel{1}{0}$

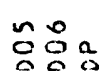

영요의

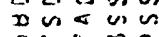

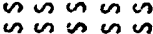

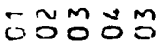

an $\bar{c}$ ma oin 0 is Nom

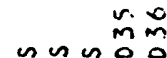
nin $\sin$ mñm 2onn nus

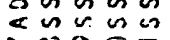

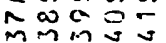




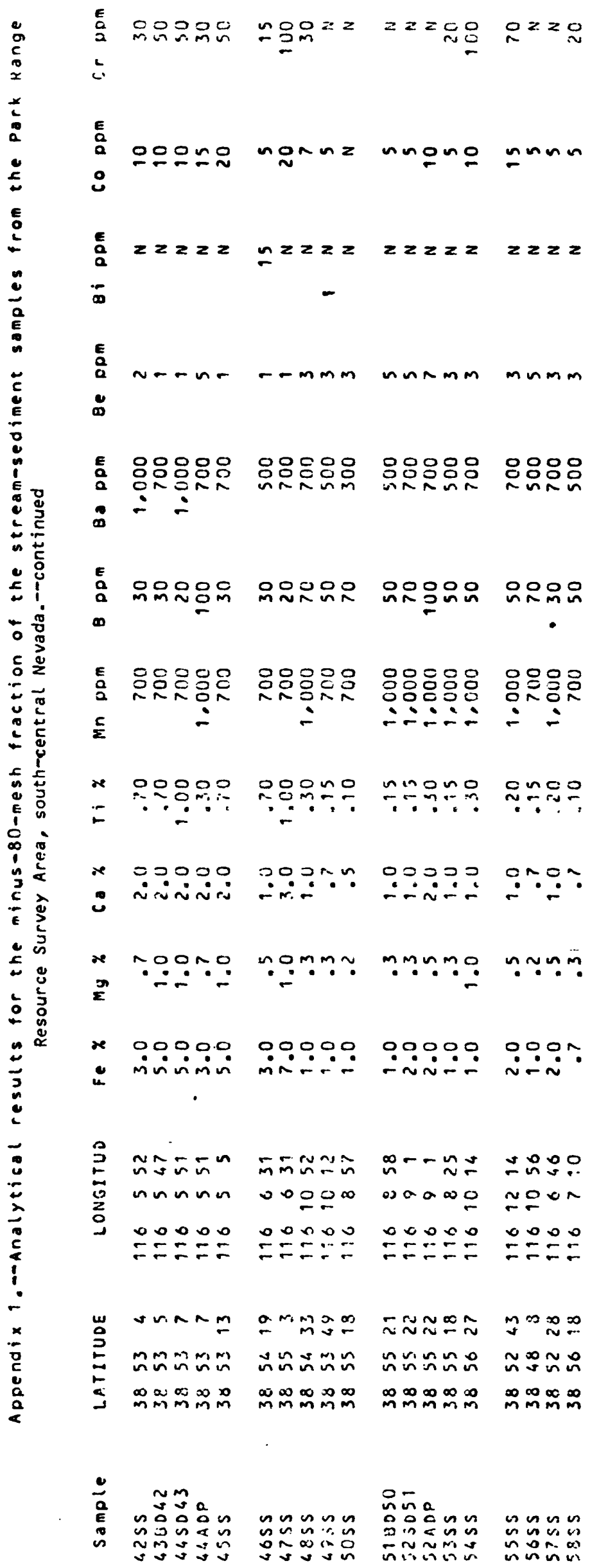




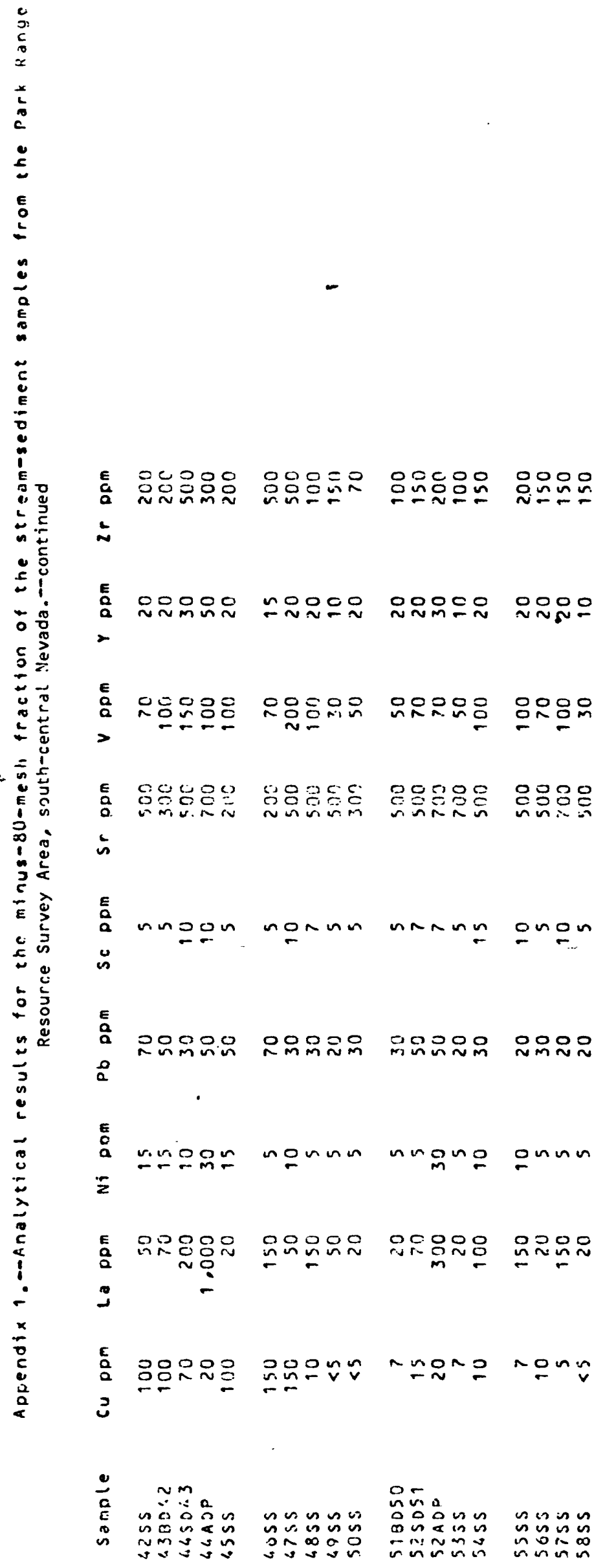




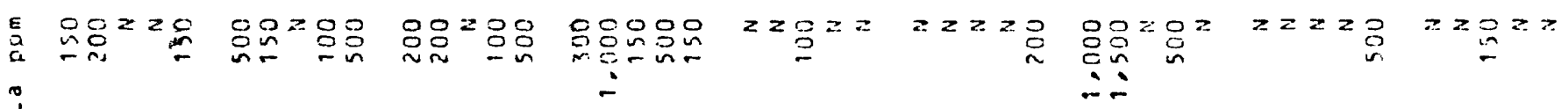

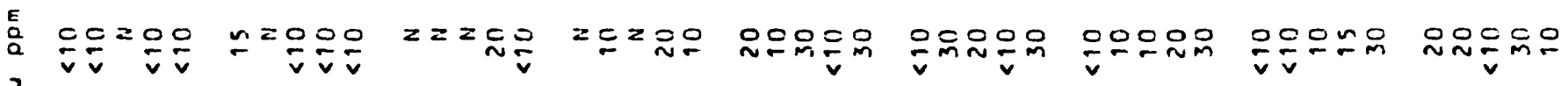
?

具 ¿.

22222

客

E

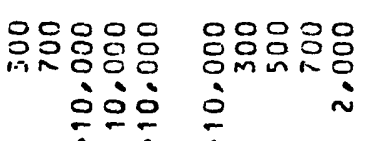

옹욤요용

응응요요

웃음웅영

용ㅇㅇㅇㅛ

in i

$\therefore-2$

웃웃옷웅

응염웃윳

$\therefore$

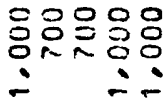

E

$\infty$

옹ㅇㅇㅇㅛ $\sim \tilde{v} \tilde{v} \tilde{v}$

응ㅇㅇㅇㅇ $\sim \underset{v}{\sim} \mathbb{v}$

웜요

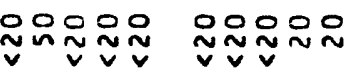

음 c

음은ํํ응응 i. $-\dot{0}$

$x$

:

ooroo $\ddot{\sim} \div \dot{\sim}$
․․ㅇㅇㅛ

$\therefore \therefore \therefore$

등의응

$\because 00 \%$.

응유은응

onoon

$\dot{0} \div \dot{0}$

00000
$\therefore$ ㄴำ

웅ㅇㅁ옹

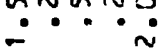

웅응ㅇㅇㅇ

$\because \div \frac{n}{n}$

운으눈

은은은

옹워은

oogno

o. 0 \% 0

inini

$\operatorname{momo}$

$\because \because \div$ i

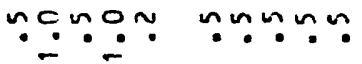

กักก

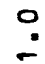

$\because$
은웅ㅇㅇㅇ $\tilde{v} \sim \tilde{v} \tilde{v}$ $\underset{\sim}{\sim} \underset{v}{\sim}$ 윰ำ

온온윤ㅇ $\tilde{\sim} \tilde{v} \tilde{v} \mathfrak{v}$

notyo oinmo ๑กำแ

Onmn

g.

능응

Erma $m \simeq \approx 0 \%$

이응

ogen

$000:-a$

oor a armm mmañ

00<0

00000 00000

00000

00000

00000

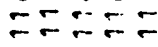

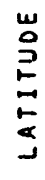

กิ๊ก๊ $5 \div-\infty=$

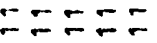

FEニ

$\because= \pm ニ$

00000

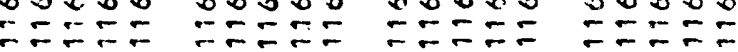

a 0000

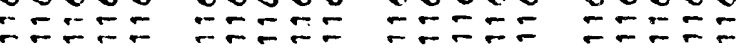

$m-\infty \infty \infty$

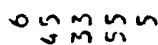

$m$ in $\sim m$

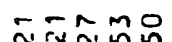

$-=-\infty n$

nammo

$\infty \infty 0$

a 007 in

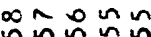

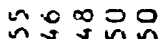

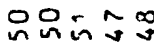

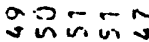
งaำ $\begin{array}{lll}\infty & \infty & \infty\end{array}$

$\infty m \infty m \infty$

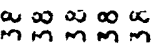

$\infty \infty: \infty \times$

$\infty \infty \infty \infty$

$\infty \infty \infty \infty$

원드

$m \infty \infty$ os

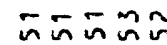

$\infty \infty \infty \infty m$

$\stackrel{\Delta}{a}$

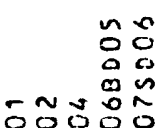

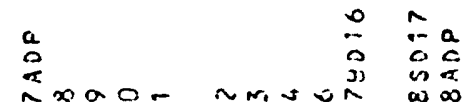

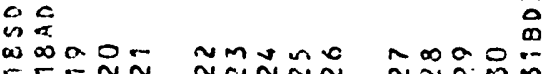

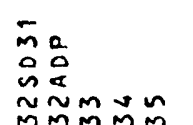

ñ.

$x$ is

$\rightarrow \hat{m} \sim \stackrel{\infty}{m}$

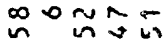
arumn

00000

ปูก

กิงnำ

$00=00$ iñ $\dot{\sim}$

$000=0$ $\because \therefore$

$\because 000$ $\infty \infty \infty \infty \infty$ MmMm 


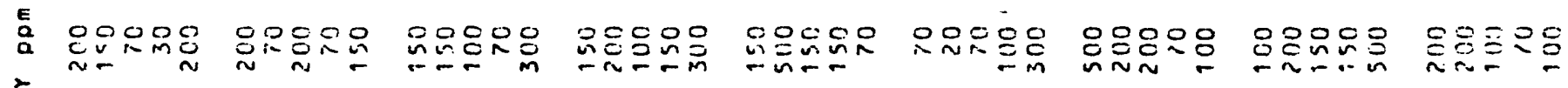

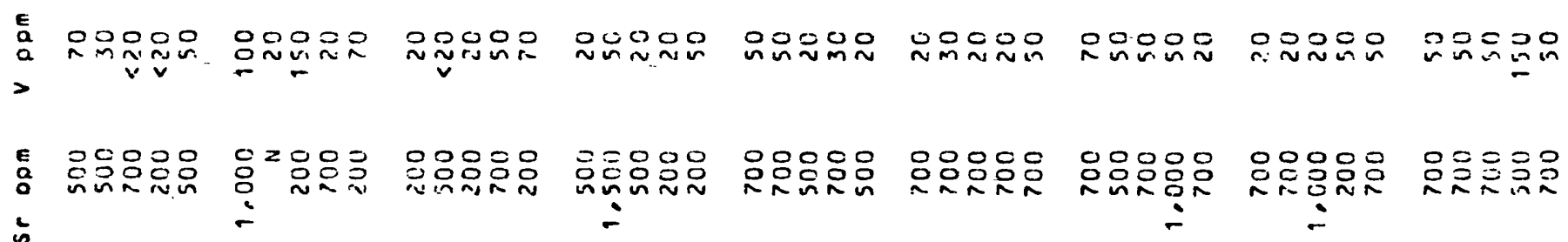

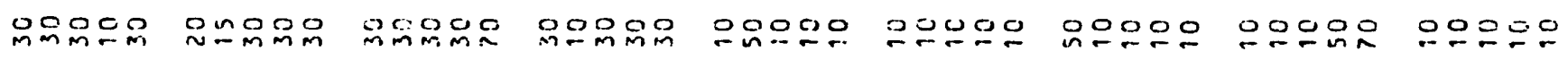
is

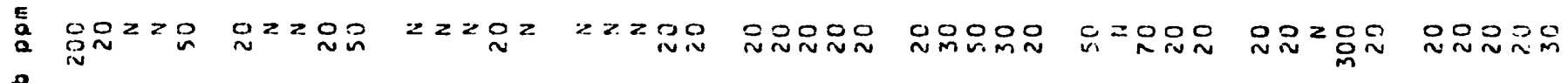
a
를

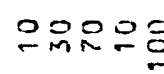
음우오오.
g요우요
우웅ㅇㅇ웅
우으모오 우무응ㅇ
웅ㅇㅇㅇㅇㅇ 우우몰르
प0000

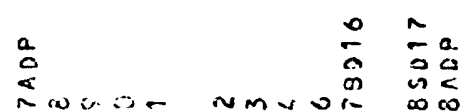

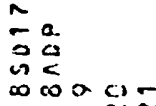
กับกัก

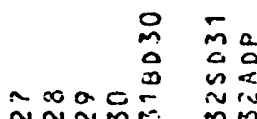
票京
$\begin{array}{ll}n & 0 \\ \text { mina } & 0 \\ 0 & 0\end{array}$

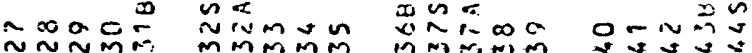




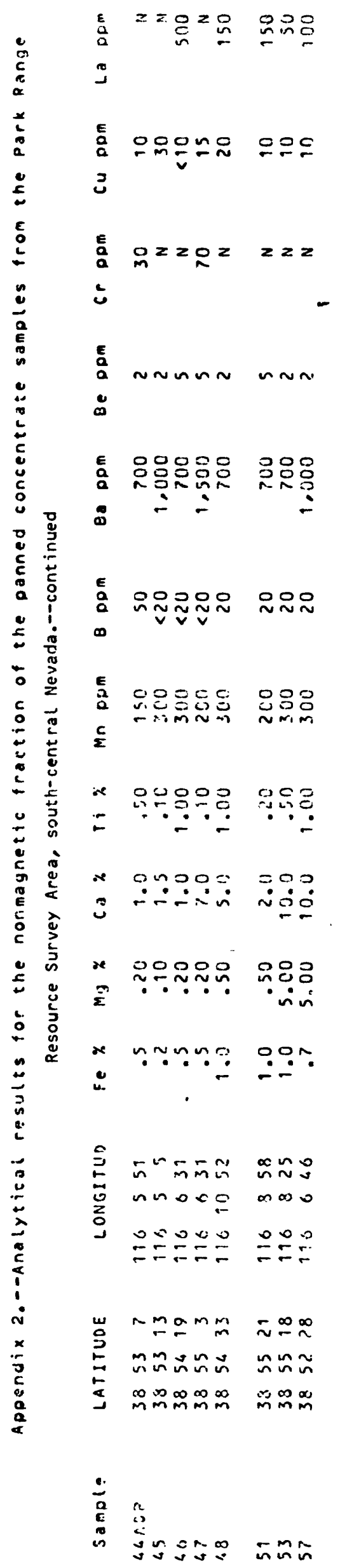




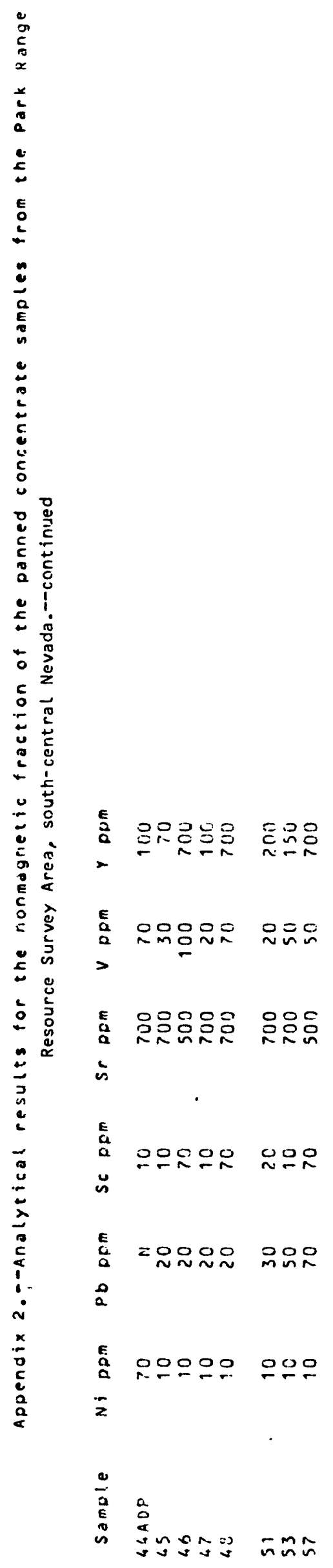

